\title{
PROFESSOR OF CARDIAC SURGERY JĀNIS VOLKOLĀKOVS (28.04.1931 - 12.12.2020)
}

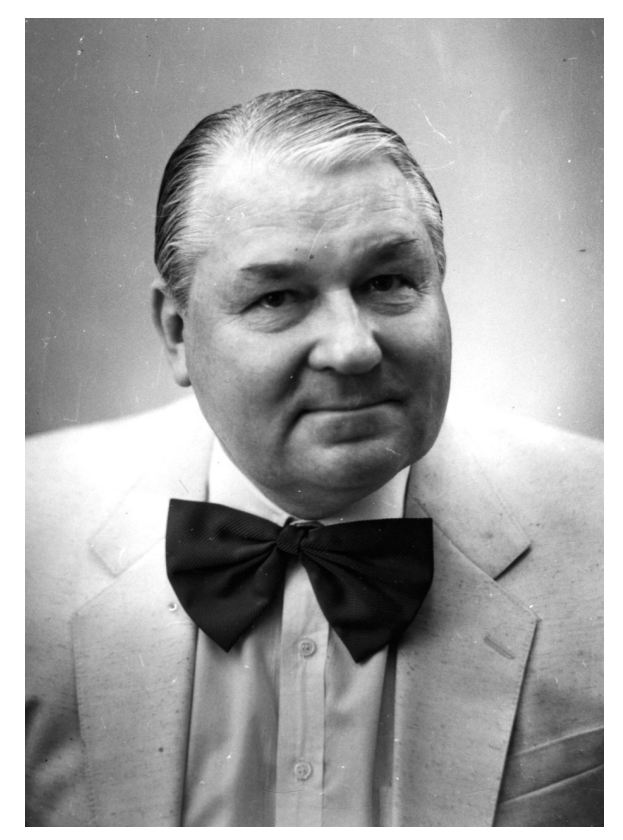

Professor Jānis Volkolākovs, full member of the Latvian Academy of Sciences, Scientist Emeritus, heart surgeon, passed away on 12 December 2020. He was one of the most outstanding post-war surgeons in Latvia. Jānis Volkolākovs started his professional career as a general thoracic surgeon, a pioneer of oesophageal plastic surgery and, together with Professor Jānis Gaujēns, also a founder of paediatric thoracic surgery in Latvia. The larger part of his professional work, however, was devoted to major vascular surgery and to the development and advancement of congenital and acquired cardiac surgery. J. Volkolākovs performed the first procedures using cardiopulmonary bypass. He also established and headed the Centre for Cardio-Vascular Surgery at Pauls Stradiņš Clinical University Hospital, and later the Centre for Cardiac Surgery (1969-1998).

During his study years, J. Volkolākovs actively participated in the Student Scientific Society and grew fascinated with surgery and performed his first operations before 1956, when he graduated from Rìga Medical Institute with honours. He completed his initial clinical training at the Department of Traumatology and Abdominal Surgery of Rīga City Hospital No. 1. His postgraduate studies in the Department of Traumatology and Orthopaedics and later in the Department of Paediatric Surgery laid the basis for his doctoral thesis on retrosternal oesophageal reconstructive surgery with the use of colonic graft (1963). In parallel, J. Volkolākovs worked as a staff surgeon at Rīga 1st Children's Hospital and Rīga City 2nd Hospital.

At the turn of 1961 and 1962, he concluded a three-months internship at the Institute of Experimental Medicine and Biology in Novosibirsk, where he advanced his knowledge in congenital heart surgery under the guidance of the outstanding Professor in cardiac surgery Evgenii Meshalkin. In 1962, J. Volkolākovs, together with his new Novosibirsk colleagues Meshalkin, Frantsev and Fufin, performed the first three successful tetralogy of Fallot surgeries at the Children's Hospital in Rīga, as well as a patent ductus arteriosus (PDA) closure operation. In parallel, together with J. Gaujēns, he undertook a series of extremely complex general thoracic operations, which came to be considered as the beginning of paediatric thoracic surgery in Latvia.

J. Volkolākovs' career progressed rapidly, regarding both his surgical skills and research. On 1 February 1964, he performed his first successful cardiac surgery for a 10-year-old 
boy with aortic coarctation using a cardiopulmonary bypass. In those times this was a significant achievement and will remain inscribed in golden letters in the history of Latvian surgery. Over the next five years, a total of 40 procedures using cardiopulmonary bypass were performed.

From 1963, J. Volkolākovs worked at the Central Scientific Research Laboratory of Rīga Medical Institute (RMI) as a research associate, focusing mainly on extracorporeal circulation. In 1968, he defended his habilitation thesis "Operative Treatment of Congenital Heart Disease in Infants and Young Children". His dissertation was the first major scientific study in the former USSR on congenital heart disease surgery in children during the first three years of their life.

In 1969, when the Latvian Centre for Cardio-Vascular Surgery was established at Pauls Stradiňš Clinical Hospital, the young and talented surgeon Jānis Volkolākovs was appointed as Head of the institution. One of the main focuses of the centre was congenital heart defect surgery. Among the most significant achievements of J. Volkolākovs in this field was the first radical correction of tetralogy of Fallot under conditions of deep hypothermia and extracorporeal circulation in Latvia (1970), aortopulmonary window closure (1971), repair of a common atrium (1971), complete atrioventricular canal repair (1973), anomalous pulmonary vein drainage repair (1974) and correction of the Ebstein anomaly (1975). During the first thirty years of his work, the Latvian Cardiovascular Surgery Centre performed 3545 congenital heart defect procedures under the supervision of J. Volkolākovs.

Complementary to his achievements in cardiac surgery, J. Volkolākovs increasingly gained acknowledgement as a scientist: a cardiovascular surgery research laboratory was established at the Latvian Cardiovascular Surgery Centre, where haemodynamic changes during and after surgery were studied, as well as myocardial protection during cardiopulmonary bypass, coronary artery bypass grafting techniques and methodology, morphology of congenital heart diseases and minimally invasive correction possibilities. Research was carried out within the framework of longterm international programmes in cooperation with researchers from the USA and other countries; international symposia and exchange visits were organised. In 1973, J. Volkolākovs, together with a group of professors $\mathrm{Bu}-$ rakovsky, Konstantinov and Frantsev from Moscow, received the USSR State Prize for diagnosis and surgical treatment of congenital heart disease at an early age, which was one of the highest State awards in science during the Soviet era.

Another important activity of the Latvian Cardiovascular Surgery Centre was the diagnosis and surgical treatment of acquired heart disease. The most important achievements of J. Volkolākovs in this field were the first implantation of a pacemaker in Latvia (1970), the first successful repair and replacement operations on the aortic valve (1971) and mitral valve (1972). From 1969 to 1999 , the centre performed
1674 valve replacements and 550 valve repair surgeries, including commissurotomies.

J. Volkolākovs, as the Head of the Centre, has significantly promoted and supported the development of coronary surgery in Latvia: in terms of the number of procedures, coronary surgery gradually surpassed valve surgery. J. Volkolākovs is also considered to be the founder of cardiac oncology in Latvia: in 1974, he performed the first successful extirpation of a left atrial tumour.

In 1987, a newly established Cardiac Pacemaker Ward was added to the Cardiovascular Surgery Centre. J. Volkolākovs was the first to perform open division of atypical cardiac conduction pathways in the case of WPW syndrome (1988).

The energy and persistence of J. Volkolākovs has contributed not only to the development of cardiac surgery, but also to that of vascular surgery. He was the first in Latvia to perform successful porto-caval anastomosis (1965), abdominal aortic aneurysm resection (1970), renal artery repair and replacement surgery (1972), resections of ascending and descending thoracic aortic aneurysms (1975).

Academician J. Volkolākovs is the author of 485 scientific publications, five monographs and a similar number of textbooks (together with co-authors).

When Latvia regained her independence, Professor Volkolākovs was invited to join the Latvian Academy of Sciences. He was elected corresponding member immediately in 1992, and full member of the Academy in 1994. At the Academy, Professor Volkolākovs joined the Department of Chemistry and Biology and represented clinical medicine. He became one of the most active members of the department, performed expert examinations entrusted to him with a great sense of responsibility, wrote reviews and gave recommendations. Special mention should be made of Professor Volkolākovs' pro-active work in the Latvian delegation at the European Academy of Sciences and Arts (Academia Scientiarum et Artium Europaea). One of the first events of the European Academy in Latvia was the 1st Baltic Conference of Cardiac Surgeons in Rìga, in 1993, and Professor Volkolākovs was its principal organiser.

In addition to his everyday work as a heart surgeon, Jānis Volkolākovs made a noteworthy effort to pass on his experience to the new generation of doctors and surgeons. He was undoubtedly one of the best experts in the history of Latvian surgery. From 1969 to 1995, the Professor headed the department of General Cardiovascular Surgery at Riga Medical Institute. The power of his personality and his passionate lectures have certainly left an imprint on every student. For many years, J. Volkolākovs was the Head of the Latvian Association of Cardiovascular Surgeons and the Vice-President of the Latvian Association of Surgeons.

In 1998, J. Volkolākovs was awarded the Order of the Three Stars, in 2002 he received the Pauls Stradinš Prize for 
his lifetime contribution to medicine, and since 2007 he has been an honorary member of the Latvian Medical Association. In 2015, Professor Volkolākovs was awarded Rīga Stradiňš University Annual Award for lifetime contribution to the development of the University. In 2019, at the $50^{\text {th }}$ anniversary celebration of the Centre for Cardiac Surgery, Professor Volkolākovs in a solemn ceremony received a letter of praise from the President of Latvia Raimonds Vējonis and the "Heart of Gold" award, which is the highest evaluation in heart surgery in Latvia.
As we look back at the life of Academician Jānis Volkolākovs, we see that it has been a path of attainment. He has saved the lives of countless patients and laid a solid foundation for Latvian cardiovascular surgery. A new and strong generation of surgeons has been successfully brought up. We are deeply grateful for the rich heritage that our distinguished Professor has left for Latvian medicine.

Sit tibi terra levis.

Pēteris Stradiņš

Profesors Jānis Volkolākovs bija sirds k̦irurgs, Paula Stradiṇa Klīniskās universitātes slimnīcas Sirds kirurğijas centra izveidotājs un vadītājs no 1969. līdz 1998. gadam. Visu mūžu veltījis sirds kirurğijas nozares attīstībai Latvijāa, veicis pirmās operācijas mākslīgajā asinsritē gan iegūtu, gan iedzimtu sirdskaišu pacientiem. No 1965. līdz 1995. gadam bijis Rīgas Stradiṇa universitātes (Rīgas Medicīnas institūta) Vispārīgās, sirds un asinsvadu ķirurǵijas katedras vadīiājs, Latvijas sirds un asinsvadu ķirurgu asociācijas vadītājs un Latvijas Kirurgu asociācijas viceprezidents. Profesors bija Latvijas Zinātṇu akadēmijas īstenais loceklis, Eiropas Zinātnuu un mākslas akadēmijas loceklis, valsts emeritētais zinātnieks, Paula Stradiņa balvas laureāts un Triju Zvaigžņu ordeņa virsnieks. 2015. gadā profesoram J. Volkolākovam tika pasniegta RSU Gada balva par mūža ieguldījumu universitātes attīstībā. 